\title{
VALUES, SUBSTANTIALITY, AND PASSAGE OF TIME: REPRESENTATIONS AND REINTERPRETATIONS OF MILITARY HERITAGE
}

\author{
Dagnostaw Demski \\ Institute of Archaeology and Ethnology \\ Polish Academy of Sciences, Poland \\ e-mail:d.demski2@gmail.com
}

\begin{abstract}
The article examines the subject of post-Soviet military bases in Poland, and deals with two main issues: 1) presenting such sites as entanglements of place, materiality, military and symbolic elements in the process of creating commonality, and 2) regarding them as products of local "imaginings" and external touristic expectations. I look at how ways of constructing heritage are shaped and constructed through locals' encounters with tourism. Following this, I claim that the defining criteria of what can be regarded as heritage relevant to accompanying transformations of original functions of military sites or post-Soviet military bases involve value, substantiality, and the passage of time. To elaborate on these research questions, I draw on data from two places where the Soviet Army was deployed: Borne Sulinowo, along with Kłomino, and Międzyrzecz, with Kęszyca Leśna. The differences in size, function, and proximity to bigger cities are factors that helped to determine the distinct ways in which the local people dealt with the Soviet military presence, and how the foreign military past can be used in the process of handling different types of tourists, those interested in nature, often well-preserved near the former military space, those interested in history and those following the trail of military issues (e.g. fortresses, bunkers, and fortifications). The sites for local inhabitants are where they live, for tourists they are places to see, and for some people they can be interesting spaces to set up military camps or fortresses.
\end{abstract}

Keywords: Cold War, entanglement, military heritage, Poland, post-Soviet military base, transformation, tourism 
The camp is the diagram of a power that acts by means of general visibility. For a long time, this model of the camp, or at least its underlying principle, was found in urban development, in the construction of working class housing estates, hospitals, asylums, prisons, schools: the spatial 'nesting' of hierarchized surveillance.

The principle was one of 'embedding' (encastrement). The camp was to the rather shameful art of surveillance what the dark room was to the great science of optics.

(Foucault, cited in Rabinow 1984: 19) ${ }^{1}$

In the eyes of contemporary Poles, post-Cold War military bases date back to relatively recent times, although over twenty years have passed since 1993, when the final withdrawal of the Russian Federation military forces from Poland took place. The last Russian soldiers left Poland on September 18, 1993, and this paper was written at the end of $2016 .^{2}$

In the memories of Poles and in the mainstream public discourse, this element of history of Soviet forces stationed in Poland seems to be unpopular, and if it appears at all, it appears more in debates of historians or in a regional or local context, namely in the areas where the troops were located. For a long time, the main topic in Polish narratives about the past was the period of World War II, but in the late 2000s the socialist period of the Polish People's Republic (1945-1989) became popular. This was a sign of changes in memory. New plots, themes, and narratives appeared, and this interest in the socialist period in Poland may indicate a new stage of collective memory, adding new meanings to the view of this period. Examples of this are a number of exhibitions held in Warsaw. In 2000 the first big exhibition dedicated to the socialist time, Szare w kolorze 1956-1970: Kultura okresu gomutkowskiego (Grey in colour, 1956-1970: Culture of Gomulka's period), was held in the Zachęta Gallery of Contemporary Art in Warsaw. The exposition included actors wellknown from popular socialist films playing their former roles in the gallery. This event attracted a large number of visitors and can be regarded as the first indication, at least in Warsaw, of growing interest in this aspect of the past of Poland. Later on, two exhibitions were held at the National Museum, Rzeczy pospolite, polskie wyroby 1899-1999 (Common wealth, Polish products 1899-1999) (Frejlich 2001), with a focus on the socialist time, and Chcemy byc nowocześni: Polski design 1955-1968 (We want to be modern: Polish design 1955-1968) (Kiełczewska 2011). These exhibitions and the number of visitors they attracted may indicate that the socialist past had become relevant and an 
object of reflection in Poland. This was a new form of reflection for a generation which did not remember the socialist past well. In my opinion, in line with the prevailing interest in the period of socialism, there was also a growing interest in a variety of life expressions, from everyday life to politics, including the issue of the former Soviet military bases.

The Cold War military bases were located near places inhabited by civilians: towns and cities of various sizes, as well as villages. In this connection, by post-Cold War military bases I mean former military zones that have been adapted by local authorities and residents as places with material (buildings and ruins) and intangible (remembrance) remnants of the old military bases.

When discussing Soviet bases, it should be noted that military bases in general are a specific phenomenon with common characteristics that go beyond particular armies, periods, and politics. In general, foreign military bases occupy transitory spaces: firstly, in the understanding of their locations on routes that were strategic from the military perspective and, secondly, in the sense of being inhabited only for a short period of military service. Often, the same buildings and infrastructure served the next regime and its armies when political or military changes occurred.

In central and eastern Poland, the Soviet Army was almost invisible. ${ }^{3}$ For numerous reasons, not much was written on the subject of the Northern Group of Forces of the Soviet Army (NGF SA) just after their departure and, if at all, they were mentioned in very general terms: from a distance, so to speak. The majority of Polish inhabitants had no direct experience of encounters with Soviet soldiers, and the few contacts mostly involved the inhabitants of the western territories, close to the East German border. ${ }^{4}$

The proximity of a military base ${ }^{5}$ provided these civilians with knowledge of a certain type of reality and offered an opportunity for an encounter, for interaction, for the occurrence of a personal experience. This foreign military neighbourhood in relation to the adjacent civilian districts had both an official and public character, and an unofficial, local or private quality. ${ }^{6}$ While most of the ordinary citizens may have never encountered Soviet soldiers, in the local experience and memory knowledge of the bases was also present in the narration of space, in abandoned buildings and deserted grounds. The material remains testified to the recent presence of foreign military troops, but also offered traces of an older pre-Cold War past, perhaps marginal, yet still real. People who arrived there and settled in the deserted areas discovered "the closed, old spaces" anew: old barracks or garrison ruins, military motifs, and the surrounding nature.

Interviews with residents of towns located near the former military bases suggest that these topics belong mainly to the memory of local inhabitants. 
Since 2015, I have visited former military bases and facilities in Poland (Borne Sulinowo, Kłomino, Międzyrzecz, and Kęszyca Leśna) and Latvia (Karosta, Daugavpils cietoksnis, Mangal̦sala, Krustpils, Mārciena, Alūksne and Zeltiṇi). These visits made it possible for me to examine several cases, which provided the opportunity for comparative research. In this article, I focus on only selected Polish cases to distinguish differences within Poland: Borne Sulinowo, along with Kłomino, a small, currently abandoned settlement in the nearby forest that was built by the Soviet Army, and Międzyrzecz, with Kęszyca Leśna, ${ }^{7}$ on the outskirts of this city. Borne Sulinowo, with Kłomino, and Międzyrzecz, with Kęszyca Leśna, are comparable examples of former military spaces, differing only in size. While Borne Sulinowo (more than 4,000 inhabitants) and Kłomino were closed to civilians as was Kęszyca Leśna, locals and the military lived side by side in Międzyrzecz (approx. 20,000 inhabitants). Drawing on interviews and informal conversations with local inhabitants, I aim to show the opportunities offered through a comparison of different spaces.

I use the notions "space", "place", and "site". Most scholars refer to space as a physical location, while place refers to a more specifically designated part of space, the way in which humans intentionally and collectively change their environment, and how their surroundings shape local communities (see, e.g., Agnew 1987). I understand site as both a space and place, where space is an area, a terrain, while a place has a connection with imagination and specialisation. In other words, a place is associated with an action, with making a place. A military space indicates a zone intended for military activities, but as a postmilitary space, it shows an area designed for transformation and adaptation to local needs of both internal development and tourist expectations.

The starting point is place in the sense of a locality embracing military past or collective identity. Zbigniew Bokszański (2008: 68) has stated that the formation and persistence of a community is, to a large extent, a function of objective conditions (natural, economic, threats, etc.). The experience is no longer subjective and is transformed into objective facts when it is shared by many people for a long time (ibid.).

To discuss the military past, I use the notions "heritage" and "legacy". The distinction between the two seems clear, but it is complicated depending on the point of view. When we look at it from the point of view of the state, heritage and legacy are sometimes used in tandem, where heritage is something that is valued and celebrated, and legacy something that is there, but uncomfortable and denied rather than emphasised. However, if we look at it from the local point of view, legacy is regarded not as negative but as neutral: as something that remains of the past, in the sense of tradition and acceptance. Unlike at the state level, the choices at the local level appear to be more practical than ideological. 
Discussing sites with Soviet post-military bases, I am mainly interested in place as a particular binding physical ground, memory, and identity in the local context. Physical ground has different meanings, both for people living there for generations and for new settlers. Its image and ways of appropriating it are important in the construction of a place through different memories, as well as in the form of an embodied local collective identity. However, as Maria Mendel, when discussing inhabitants of post-war Gdańsk, has said (2010: 374), local places are no longer physical rooting points; they are increasingly abstract places, constructed and conceptualised areas. This phenomenon seems to be present in the case of areas included in post-Cold War bases. I ask in this article whether there is an attempt to preserve the past or, on the contrary, as Mendel said, "the local inhabitants are trying to maintain a balance between the abstract, dematerialised nature of these sites and their persisting despite materiality linked to the physical territory and material objects, which are carriers of remembrance found there" (ibid.).

I will discuss how the military character of the recent Cold War past influences the construction of contemporary identity and locality. I argue that the ways of constructing heritage depend on the level - either state or local - thus enhancing the question of what is acceptable from these opposite points of view. Thus I posit the question of whether former Soviet military bases can be considered to be cultural heritage.

\section{MILITARY LEGACY OR HERITAGE}

Recent decades have seen the concept of heritage undergo a profound change. Having at one time referred exclusively to the monumental remains of cultures, heritage as a concept has gradually come to include new categories, such as intangible and industrial heritage. ${ }^{8}$ This concept in our time, accordingly, is an open one, reflecting living culture every bit as much as past culture.

The issue of cultural heritage has several aspects. First of all, there is the problem of what is considered heritage and on the basis of what parameters we should classify a given space, landscape or object - tangible or intangible as part of heritage. To understand whether and what military remains can be considered cultural or national heritage, let us consider the scientific definitions of heritage.

Various aspects of cultural heritage are reflected in the extensive literature on the topic, from the classic distinction between heritage and history - preserved objects that validate memories (Lowenthal 1998 [1996]) - to postmodern authors' ideas: the past is a cultural construct and authentic ancient sites and 
objects are products of a culturally conditioned evaluation of the past (Holtorf 2001), and heritage is created in a process of categorising (Carman 2002: 22). In another definition, heritage is not only a product of the present time, but also of a long process of relating history, through which communities recognise themselves precisely as communities (Matthews 2006: 87). The focus on contemporary experience is stressed by another definition, as both non-material elements of culture, passed down from generation to generation, and material elements, such as buildings, memorials, monuments, and other objects, including archive records, are seen to form experiences to which communities refer when they construct their here and now (Albert 2007: 50). Heritage covers everything that contemporaries select from the past that they themselves have created for the use of the present or in order to pass on to their descendants (Ashworth \& Graham \& Tunbridge 2007: 32), representing history and archaeology.

Industrial heritage is comprised of the remains of industrial culture, which have historical, technological, social, architectonic or scientific value. It includes buildings and machines, workshops, manufacturing plants and factories, ... warehouses and storehouses, locations where energy is generated, transmitted or used, transport and its infrastructure... military techniques of defence and attack.... (Affelt 2009: 5-6)

Military heritage classified as industrial has to be regarded as a specific part of the past.

It is worth noting who makes what decisions about the choice and assignation of the category of heritage to a given object or place. From the scientific point of view, the defining criteria mostly involve value, substantiality, and the passage of time (Kobyliński 2009). An object or a place is prominent due to being a vehicle of certain values for human culture, most frequently understood as connected with the culture of the subject that determines the criteria, and thus a nation, a group, a local community, etc. Value may be of historical, social, symbolic, economic or other character. Substantiality denotes the preservation of a certain permanence of form, mostly material, which may be usable. The passage of time indicates the value of permanent artefacts that were made in the past or are no longer made, and whose financial (and other) value increases over time (e.g. works of art).

These factors - value, substantiality, and passage of time - also come into play when discussing post-Cold War military bases. Put briefly, the former Soviet military bases have no symbolic, social or historical value because from a contemporary state perspective they belonged to occupiers. Many of them are still standing, especially those that were located on top of former German buildings and fortifications. A quarter of a century seems to be too short 
a period to determine their more universal value, but in the case of older preSoviet barracks and constructions on military bases, the substantiality or the material space and buildings from the previous era meet the general criteria. Such questions are taken into account ${ }^{9}$ on the state and professional scholarly levels, where opinions help to determine official classification.

Before I move on to the issue of selection, it is important to distinguish the nature of the concept of values. Following Edmund Małachowicz (2007), the main dilemma is whether values are permanent properties of things, or exist objectively, outside things, and are attributed to things depending on the needs and predilections of their users or knowledgeable subjects. There are two distinct views. According to axiological objectivism, values are constant, although they may be unrecognised. However, according to axiological subjectivism, values change depending on time, place, and circumstances in terms of how they are attributed to objects by their users. Accepting one of these extreme views results in practical consequences. If values are objective and constant, the objects or phenomena that carry them require absolute protection. If they are relativised to place, social circle or historical demand, their obligatory character for the individuals and institutions responsible for them is weakened.

The cases of former military bases show that values are not constant: they are attributed from outside and correspond to the needs of contemporary and historical politics. Choices made and categories attributed reflect a certain way of thinking about the past or its fragments, and their evaluation from the perspective of contemporary needs. The inclusion - selection - of military bases in the category of cultural heritage in Poland faces various obstacles:

- the objects fulfilled political functions, which may be treated as a value, but they were symbolically alien from the point of view of the state, nationally and politically, i.e., subject to the rules of a foreign state;

- it appears that they have no ability to create and sustain a sense of apparent identification and social bond with contemporary people;

- even if they constitute the oldest (the first) objects of, for instance, architecture in these regions, as they sometimes do in the western territories, they do not represent continuity within the contemporary Polish culture;

- the traditional Polish distrust and caution regarding Germans and/or Soviets, embodied in historical politics on the state level.

The problem is that the places and objects functioning as former Soviet military bases from the period of the Cold War did not belong to the continuity of the Polish state and culture. Most of them were located in the former barracks and buildings constructed in the 1930s by Nazi Germany or earlier, at the turn of the twentieth century; some of them even occupied entire areas or districts that 
were separated from cities. They form a legacy left there by the then (or later) enemies, which is impossible to remember, and impossible to erase completely from memory. They may find use only as a result of the transformation of their original functions (unless they are used as barracks by the Polish military forces, as in an increasing number of cases), when tourism arrives, bringing new bodies that animate places with new imagery and expectations.

The factors discussed - value, substantiality, and passage of time - can also be considered in the context of a foreign symbolism and changing attitude towards the past, where foreign symbolism was treated negatively. In this connection, the figure of the foreign soldier as part of Polish history deserves a closer look. As a rule, it is associated with the loss of independence, partitions, occupations, and World Wars I and II. It is associated with loss and defeat. ${ }^{10}$ Many Poles served in foreign armies due to conscription (by Germany, Russia, and Austro-Hungary), but there is also the tradition of mercenaries, which has not been widely discussed. Poles also served in American, British, and French armies, as well as with Turkish troops (in the Russo-Turkish War). Both the presence of foreign uniforms ${ }^{11}$ and Poles wearing foreign uniforms are historically common phenomena. The Polish uniform emerged in this context as a symbol of a glorious past; it symbolises sacrifice but it is also associated with hope for the future.

Another point is the historical differentiation of the territory of Poland. As was mentioned above, Soviet military bases were located in the western part of Poland, which means that there is no tradition regarding these bases in relatively recent Polish history; in this sense, there is no collective memory, and no state or national continuity. The central, southern, and eastern parts of Poland vary, having a variety of connections to Polish history, including big or small military issues. They offer different understandings of local spaces, as communal spaces are recreated in the present through the view of the longer history.

The presence of Soviet troops thus forms part of a broader discussion of foreign armies and uniforms, but this is a subject for a separate study. PostSoviet military bases were a vestige of World War II, a continuation of the division of powers, yet in a new form - that of the Cold War. It was not a simple continuation, however, as it resulted from the end of another war. The division of powers, similarly to the national affiliation of numerous military bases, changed after World War II.

To recap, the motif of the presence of foreign military forces, of foreign uniforms, has repeatedly occurred in the history of Poland and does not make it possible to consider these places as heritage or to use their remains, with their accumulated symbolism. Often, people have lived in the shadow of a fortress 
for a long time, but almost every generation encounters another army and different uniforms.

Heritage is a product of contemporary times, of a culturally, socially or even politically conditioned evaluation of the remains of the past. ${ }^{12}$ The goals for such an evaluation are formulated centrally, e.g., by the state, but also at the local level. In consequence, it is necessary to stress that appropriating a site, remains, and local people is a continuous and changeable process. The symbolic value factor determines that the post-Soviet military bases cannot be seen as cultural heritage on the national or institutional level.

The local level represents another perspective, especially after an encounter with tourism, which provides "another poetics" (Crouch 2008 [2002]: 210). Inhabitants and visitors see local history through traces of the past in buildings, the layout of old streets, ruins, monuments, and military objects on a base. A variety of interactions enable them to see, touch, feel, and discuss features of the former military landscape, and thereby sense it as a place through intermingling and communicating with what was left at the place.

Architectural objects, old and new, the layout of a place and buildings of remembrance constitute the space in which the local community forms. If the postCold War military bases are not national heritage, what should be done with them? It depends on the local community. The main buildings not considered to be heritage because of the lack of connections with the history of the country and the nation can still be used for touristic purposes. A local community can take advantage of the military aspect, other elements of the military landscape, and the presence of foreign uniforms to place itself in the circle of military interests in a universal sense, and not only in the sense of local history. What is not recognised as national heritage may still be of interest to specific tourists who are not interested in the sides of conflicts, victims and persecutors, losers and winners, but in the military past and related matters. Tourism emerges as a new factor shaping local space into a new context, thereby "enlivened and endowed with meaning through the practices of the tourists" (Massey 1994).

\section{MILITARY MARKET AND A MODEL OF MILITARY SPACE}

As David Chaney (2008 [2002]: 200) put it, "tourists are regarded as consumers of public places of the other cultures", just like in all of the cities of Poland, which have opened up to tourism, exposing the landscape, architecture, past or nature, depending on the resources available. This also applies to sites with former military bases. 
Objects related to everyday military activity in the form of manoeuvres and training (e.g. bases, barracks, and training grounds), or objects connected with military activity (e.g. battlegrounds) belong to the category of military objects. Marie-Louise Sørensen and Dacia Viejo-Rose (2015: 1) call them places created as a result of wars, conflicts, and their aftermaths. The material traces, remnants of the memories of people living in the area, are subject to individual interpretation. At this point, however, I am focusing on military tradition not as traces but more in terms of thinking and acting, or lifestyle. These are part of military tourism, a sphere closely tied to the issue of heritage.

If tourism makes places exhibited (Coleman \& Crang 2008 [2002]), what can we say about the former military places? This kind of military heritage seems to be relevant for analysis because "different products for quite different markets can be created from the same raw material by varying the interpretation process" (Ashworth \& Haan 1986). We can thus speak of a "military market" or areas of military interest. These are formed in response to specific needs and are shaped to meet the requirements of a specific group of visitors and users interested in military themes generally as part of a longer tradition. In this sense, tourists are interested in both the contemporary remains and the past functioning of the bases themselves. As was mentioned above, in the territory of Poland the Soviet Army was mostly housed in military buildings built earlier, mainly by the Germans. Some were constructed before World War I ${ }^{13}$ and others were built in the 1930s. ${ }^{14}$ For example, Kęszyca Leśna, near Międzyrzecz, was built entirely atop German military structures. These topics were discussed in interviews and conversations conducted in the field, leading me to conclude that for fans of military tourism the contemporary situation seems not to be very important; they are interested in military remains, architecture, and the layout of places.

Borne Sulinowo offers great attractions due to the fact that the town grew entirely within the boundaries of an old military base built by Germans and used by Russians. In Miedzyrzecz, the Soviet Army occupied the buildings of former German bases in the city and a smaller base in Kęszyca. Military structures, especially in Borne Sulinowo and to a lesser extent in Kęszyca Leśna, therefore were parts of closed military areas. For fans of military matters, they are also interesting because they resemble many other military structures of this type, built in the 1930s. This opens up another dimension, a world of major military structures, and for tourists it offers yet another military model.

In local communities, the tourism factor offers a new framework within which local inhabitants' contact with guests arriving in their space affects the forms of existence. Following David Crouch (2008 [2002]: 207), it could be argued that space becomes a peculiar medium, meaning that in the face of experiencing 
the same space by two different groups (locals and tourists), after a new space is perceived, objects and artefacts valued as belonging to the local space and landscape slowly become objects participating in a consumption process. As a military model, this space is seen not as a post-Cold War base in Poland, but as belonging to the military concept of a series of citadels, battlefields, and fortresses, and in this sense to the category of military thought and military practice. This kind of military practice can be observed or researched in Borne Sulinowo, mainly through the template spatial plan and architecture. This is not possible in the case of Miedzyrzecz, where barracks were located in the city amidst civilian buildings.

Michel Foucault included the contemporary military tradition in the wider category of an Enlightenment trend based on discipline and order in "the form in which military discipline, political power, and religious authority are usually exercised" (Rabinow 1984: 36). Bases existed in the past but they also exist today. ${ }^{15}$ Like barracks, they formed good soldiers. Both types of military objects constituted places where soldiers were gathered, in garrisons and barracks, in their own territory, whereas military bases were associated with gathering centres, military training, and separation from the local population in a foreign territory.

Often, when we visit a certain place, we see changes, some of which have resulted from the needs of the inhabitants and others from the expectations of tourists. Tourists bring different imagery and experience. Crouch (2008 [2002]: 208) writes that a tourism site is a "field of action predicated by its representations". Tourists often come with images of the sites in mind, created by promotional sources, and what is left for tourists is a "reading of representation" (ibid.). Also in military places they construct knowledge through engagement, as the tourist practice consists of experiencing, sensing, and walking. The life of a military base turned into an attraction can be observed in Borne Sulinowo, where the site is represented for tourists through public relations and advertisements.

Miedzyrzecz exhibits historical themes: a castle, an old town, churches and monuments, and in the museum there is the historical continuity of this land with the Slavic and Polish past. Borne Sulinowo as a small town entirely constructed on top of the old base exhibits military infrastructure, buildings, a polygon, and the surrounding nature, underlining the context of the military aura. Both offer different sensations of space.

Sites of this kind are products of both local "imaginings" and external touristic expectations. In this sense, tourism has generative power at the sites, "eroding innate and specific values of places" (Relph 1976). Some of the former ordinary cities and towns with military pasts have been transformed to satisfy the expectations of tourists. Tourist trips entail the production of standardised experiences for newcomers. 


\section{LOCAL ORAL TRADITIONS DURING AND AFTER THE COLD WAR}

The Cold War is illustrated for tourism as buildings, signs, monuments, training-grounds, and barracks. However, tourism as a practice is not just about viewing, but also about storytelling, creating symbolic sites, and exhibiting objects and data in local museums, which can be observed in Borne Sulinowo and Międzyrzecz.

In contrast to World War II, there was no large-scale fighting directly between the two sides during the Cold War, although there were major regional wars, known as proxy wars, supported by the two sides. The Cold War split the wartime alliance against Nazi Germany. Although the two superpowers never engaged directly in full-scale armed combat, they were heavily armed in preparation for a possible all-out nuclear world war. Apart from the development of nuclear arsenals, and the deployment of conventional military forces, the struggle for dominance was expressed via proxy wars around the globe, psychological warfare, massive propaganda campaigns and espionage, rivalry at sports events, and technological competitions, such as the Space Race.

In general, the Cold War and its events have left a legacy that is often reflected in popular culture, especially in the media, featuring themes of espionage and the threat of nuclear warfare.$^{16}$ On the state level, the Soviet Union sought to dominate the internal affairs of countries. The Soviet Union set up secret forces loyal to Moscow, and local communist rulers took control of the media, then banned all independent civic institutions.

Unlike "hot war", with its large numbers of victims, the Cold War imposed specific frameworks that had little effect on the local population. The presence of foreign soldiers could be associated by locals more with mutual individual benefit than with a wider threat. ${ }^{17}$ Interviews with the early inhabitants of Borne Sulinowo show that they had not heard of close contacts with senior Soviet officers, but they told stories confirming contacts with lower ranking soldiers, mainly consisting of buying fuel or goods available only on the bases. The presence of the Soviet soldiers was officially rigidly ideologically controlled, but on the local level there were contacts; officers had contacts with Polish Army representatives, and low ranking soldiers had contacts with the local people.

For propaganda reasons, during the socialist period images of foreign soldiers on the bases, incompatible with the official guidelines, were not shown. Narratives of this type appeared either in jokes or in the anecdotes of the inhabitants in the areas near the former bases. In accounts of military bases, the classic division of us/them was applied, although the tone of the narratives was not necessarily hostile: on the contrary, it often indicated mutual informal relation- 
ships and dependencies. When access to the bases was forbidden, there was a "miraculous renaissance of the oral tradition" (Bloch 2008: 300). In the past, the taboo subjects in tales about the bases included such issues as the soldiers' attitudes, the military incompetence of the commanders, malfeasance, conservatism, ignoring of information and poor administration. After the withdrawal of the foreign troops, these subjects came to the foreground; there are examples in the local newspaper Moreny: Gazeta Krainy Jezior i Lasów (Moreny: The Paper of the Land of Lakes and Forests), published in Borne Sulinowo since 1993.

\section{POST-MILITARY LOCALITY OR VARIOUS FORMS OF ENTANGLEMENT}

The post-Cold War landscape emerged in Poland in the 1990s. There are various views regarding it and there are a number of representations and contested interpretations of the past (for a longer discussion on this issue, see Demski \& Czarnecka 2015 and Czarnecka 2015b). A landscape is a patch of land that has some sort of socially created unity as a result of the behaviours of people who act within it, or the meanings they ascribe to it, or both (cf. Hirsch \& O'Hanlon 1995). Cultural activity leaves traces - deliberately or inadvertently - on the landscape, with subsequent cultural activity that transforms it, especially in connection with tourists' expectations. The information contained in advertising and promotional materials created for tourists is not recognised and applied by locals. The image of the socialist past is more complicated.

Remembrance of the distant past does not change much, although it is subject to reinterpretation. I believe that in Poland the memory of World War II is a kind of model, a pattern of speaking about the war. In this context, memories of the Cold War period are subject to more pronounced changes. Perhaps we are still more in the phase of the memory of individual witnesses than in the phase of creating a collective memory through the tools of official memory politics. ${ }^{18}$

Apart from changes brought about by tourism, we are witnesses of something else: the transformation of what was remembered and what will be remembered, to some extent differently in state and local communities' memory politics, making choices alongside various social, historical, and economic trends and achieving different goals. This involves the near past, and its description is difficult because we do not know what the final outcome of these transformations will be.

Frequently, the remaining inhabitants, witnesses of the Soviet Army presence, focus on other threads than do those who had no direct involvement with those events. The difference is associated with the fact that histories have personal and emotional characteristics, and places evoke memories of concrete 
events and interactions. For descendants or readers from afar, many of these emotions, images, and experiences are not significant: a distant picture, a kind of synthesis is enough for them. Some memories or experiences will survive in family lore; they will remain as family stories which contradict official interpretations but, being quite personal, will not spread outside of the family.

The former Soviet bases, such as Borne Sulinowo and Kęszyca Leśna, became living spaces for locals. Events, situations, and experiences either remain in memory or are captured/preserved in the form of photographic frames. Live situations, social interactions, mutual relations during meetings with other people, personal experiences and impressions resulting from them, collective and individual experiences - all of these contributed to the everyday life of the former inhabitants of the place, and today are the last remaining witnesses of those events. What remains? Stories told by witnesses, second-hand reports, and accounts by their children or acquaintances, partly written down in interviews from those years, partly in memoirs, sometimes in unpublished personal journals.

In the stories about the Soviet military, told by contemporary inhabitants, information from multiple sources dominates. These memories and images are conveyed via novels, interviews, articles, reports, other literature, photographs, museums as institutions that preserve memory, public debates and exhibitions, and the main motifs include pioneering, experienced traumas, familiarisation of space, its reclaiming, making choices, and attributing credibility to the choices of one's parents and grandparents.

The cases of Borne Sulinowo and Miedzyrzecz differ greatly, as the former has a totally new population, and the latter has preserved the continuity of the majority of Polish population since the 1950s. The memories of the pioneers shaped the process of reclaiming the post-Soviet base, forming contacts with the base, cooperating, and getting to know the other side. Originally, the memories of the other side, of the soldiers who left, were insignificant. Nowadays, when the presence of new inhabitants in the territory has been established, the subject of the military past attracts increasing interest. As attempts to transgress their own context, we can regard the narratives as those of pioneers, the founders of a dynasty, everything made anew, becoming familiar with the space, houses, and domestic situation. As this period matures for musealisation, we have to remember that for the local inhabitants the subject still has strong resonance in the present.

In this phase, a desire to fill the "blank pages" in the local history may emerge, to widen the discussion of whom they notice from that period. The educational function and the function of commemorating what was there are developing. As interviews conducted in Borne Sulinowo showed, the soldiers' 
plight is not of interest to the local population; rather, they focus on the fate of the common people.

Writing about the ways of presenting World War II, Bartosz Korzeniewski (2015: 119) remarked on the idea of "giving back face", in the sense of individual identity, to the war victims in the museums of martyrdom located in former places of torment, i.e., former concentration camps. On the former bases, no one gives back face except for a former photographer of the Soviet Army and occasional events. In Borne Sulinowo, there is a permanent exhibition of photographs from the German and Soviet times on the walls that separate the town from the training ground; special tours are organised for German tourists, etc. Nevertheless, a number of photographs remain in private collections both in Międzyrzecz and Borne Sulinowo.

The changes are related to the way in which this past and inhabitants' experiences are interpreted. The time has come to tell the history through the eyes of witnesses who remember it and through participants' accounts of individual experiences. The cases of abandoned bases, where there are only buildings left in ruins, are examples of a landscape that nobody cares about for various reasons. Some are abandoned because they lie far from the main routes (e.g. Kłomino), reflecting the weight of the economic concern. Moreover, the abandoned sites have no social significance for contemporary people, and no political or historical functions.

The military aspects of the bases still remain in the foreground for locals, but this is even truer for tourists (in Borne Sulinowo, not in Miedzyrzecz), and the connections of the military forces with the area are not officially emphasised on the local level. Today I would say that what matters to tourists ${ }^{19}$ are the torn down walls, the architecture, found artefacts, the history of familiarisation, old photographs, uniforms, paramilitary objects and objects for sale, as well as events organised for them. The numbers and names of the victims of the camps, the names of the dead who are buried in the cemeteries, the training ground, the wild space and nature preserved due to the existence of closed-off, former military places remain blank pages.

If the power of the military camp as a place acts upon people through its visibility, which Foucault understood as controlling (Rabinow 1984), then tourists come to see, to feel, and sometimes to experience this type of control, most often in terms of what is obscure and informal, and what cannot be considered heritage in the institutional sense. Places that have been preserved almost entirely on the plan of the military camp, such as Borne Sulinowo, are examples of this. Miedzyrzecz, as a larger city, has a wider tourist appeal (a castle, old tenement houses, the old layout of streets, museums, spas, cafes, and discos). And for this reason, in spite of the Soviet Army's being stationed there, today the city is not associated with military tourism. 
If there is nothing to praise, or to be proud of, are the former military bases things we need to know about? Do they have any potential iconic visibility as real estate? Whether these places are just "heritage of war" or are places that participate in the recovery and remaking of communities (Sørensen \& ViejoRose 2015: 1) depends on the interpretation of the past, and interpretations other than the official version of the past - local or regional versions - are a part of this process. Differences occur at the crossroads of state and institutional policy (e.g., regarding a museum) and the contacts of the local population with the tourists visiting the bases.

Post-Soviet military bases as the remains of the Cold War refer to places of frozen conflicts, where a new phase of open conflict cannot be excluded. Frozen conflicts are those in which violence has ceased, along with the presence of military bases, but where there is a lack of resolutions that have been generally accepted, however reluctantly. This implies that at least one of the parties feels that issues have been left unresolved, including perceived ongoing injustices. ${ }^{20}$ In frozen conflicts, one or more parties often tend to cultivate narratives about the other as the enemy. These frozen conflicts tend to come about when a new order is imposed by actors who do not tolerate the continuation of the conflict. When it is not possible to resolve a dispute, it is moved into the background and remains "stuck" there, in a space that is neither officially discussed nor spoken about on a daily basis.

The withdrawal of armed forces from Central and Eastern Europe was heralded as the conclusion of conflicts over post-military bases and their aftermaths. Recent events have demonstrated that this is not necessarily so, ${ }^{21}$ and that the usefulness of these spaces did not end with the passing of the previous period.

\section{CONCLUSION}

Former Soviet military bases were, at least in part, areas closed off or inaccessible, and frequently unmarked on official maps. Despite their invisibility, they certainly were places distinctive due to the contrasts (military character, foreign jurisdiction, different culture, etc.) with the local population. They became emblems and measures of the Cold War era on more than the regional level, were always present in the minds of the inhabitants, and after the withdrawal of the Soviet Army were staged for tourists.

At least some of the former military bases disappeared. They disappeared faster than the monuments connected with the Soviet Army, although the monuments only served a symbolic function (Czarnecka 2015a). On the other hand, if the bases find other uses, they are preserved in a material sense. ${ }^{22}$ 
Sites disappear when the material parts crumble, memory loses its former function, and people's sense of a place turns in a new direction. However, it is not possible to totally erase the Cold War past. Contemporary residents remain rooted in both tangible legacy and material objects. This provides a sense of commonality entangled with the physicality of the place, the past circulating through local memories, regional institutions, and the ability to use legacy to develop the place for inhabitants and for tourists.

The compelling charm of the past makes it possible to state that the Cold War lives on, not in its real form but in the form of a lesson, entertainment or knowledge, fragmentary but fitted to the needs of the inhabitants and visitors to the area. The post-military bases are used as both the means of remembering a particular past and a medium for education, knowledge or - in a changed form - entertainment. What can be done with the bases?

The former post-Cold War military bases are a part of a past that is still difficult to deal with. They have not found places on the national heritage lists. Yet, some of the bases have been adapted and presented as local heritage, as is the case in Borne Sulinowo. New narratives, not necessarily coherent, show that these places are not always marked by the state as heritage valued, but that they have valuable stories to tell. Although not by the state, they are "invested places" owned by local communities or noticed by some external communities. Examples are the German tourists who visit the former bases, and the events which are organised there. The bases are present in the recollections of former soldiers (German or Soviet) whose fate was connected to these places.

Since these places still exist, shaped by the entanglement of materiality with changing imagination, who could invent (in the sense of Anderson's imagined communities (Anderson 1991 [1983])) the post-Cold War military bases and why have they not been invented yet? Tourism has the power to revitalise these sites, but can anything besides tourism revitalise them? In my opinion, the image of the past is subject to change, and this is determined by the passage of time and the values professed. In this sense, the next generations will invent new interpretations similar to the exhibitions of socialism in the museums mentioned at the beginning of this article.

This process depends on the passage of time. Almost twenty-five years after the withdrawal of the Soviet Army is a short period in the scale of history. Events of the Cold War in the areas surrounding Borne Sulinowo and Międzyrzecz are still remembered by their witnesses, who ascribe particular meanings to them. When, with the passage of time and the change of generations, the memories of individuals lose their significance, this period of the past will gain a new resonance and other factors will influence the future evaluation of the postSoviet military bases. 
To paraphrase the words of Marc Bloch (2008: 220) that the "ideological" character of war has lent so much beauty to sacrifice, from the contemporary point of view it can be stated that even the "ideological" character of the Cold War lent a dramatic quality to the experiences of the local population, while it also lent glory to service in the proximity of the Cold War front-line. In any event, thanks to the stories which have been told by locals and tourists - often contradictory and frequently "ideologically" spruced up - these places, located between the known and the unknown, have gained new expression in contemporary Poland.

\section{NOTES}

1 This article is based on the formulas of Michael Foucault presented in the collection edited by Paul Rabinow (1984). All references to Foucault are from Rabinow 1984.

${ }^{2}$ I discuss cases of the post-Soviet military legacy in Poland till the end of 2016; further developments related to the new government of Poland have not been taken into consideration.

3 Among the exceptions were Łowicz, Warszawa-Rembertów, Torun, and Września, not as military bases, but as military units.

${ }^{4}$ With regard to figures and geographical data on the subject of post-Soviet bases in Poland, see Czarnecka in the present issue.

5 In the cases in which the bases covered parts of towns - Legnica, Kołobrzeg, Międzyrzecz, Szczecinek, Białogard, and others - the contiguity had a more pronounced character.

6 Such conclusions can be drawn from interviews conducted in Borne Sulinowo (2015 and 2016) and Międzyrzecz (2016).

7 The system of military fortifications extends in the vicinity of Miedzyrzecz, and was known as the "Strengthened Arc of the Oder and Warta Rivers" (Ostwall or Festungsfront im Oder-Warthe Bogen). It was created by the Nazi Germans between 1934 and 1944 to protect the eastern border. There are dominant fortification structures, which in the vicinity of Międzyrzecz include military objects situated in the small settlements from Kursko through Kęszyca Leśna, and Pniewo to Boryszyn.

8 The Convention for the Safeguarding of Intangible Cultural Heritage is a UNESCO treaty adopted by the UNESCO General Conference on October 17, 2003. For more scientific discussions, see Lowenthal 1985, Hoffman 2006, Sandis 2014, and Falser 2015 .

9 In books discussing the heritage in a more general manner (Kobyliński 2009), there are no direct references to the question of the Soviet post-military remains. It seems that, from the point of view of the central government, it is a question of military use and re-use of the objects and, if this is not possible, then the issues are left in the hands of local authorities. 
${ }^{10}$ In broader terms, this is more or less a common figure in the context of Central and Eastern Europe, between Russia, Germany, and Turkey before World War I, where soldiers of different local origins served in the imperial armies.

${ }^{11}$ In the eyes of a defeated nation, the uniforms symbolise not only sacrifices on battlefields but also former and maybe future glory (Bloch 2008: 86).

12 The change in historical politics under the new government of 2016/2017 confirms that the approach to the past is a political matter.

${ }^{13}$ For example, the Boyen stronghold, constructed in Giżycko in the 1850s (Festung Boyen, Lötzen).

${ }^{14}$ For more on the subject of the history of the base at Borne Sulinowo, see Demski \& Czarnecka 2015, and Czarnecka 2015b.

${ }^{15}$ Bases also form spaces with developed defense systems. Usually they are surrounded by fences, and in order to get inside it is necessary to pass through control systems at the gates. Bases form separate complexes or even towns (as, for instance, in the case of Bagram in Afghanistan) with military and training facilities, but also with churches, discos, shops, etc. At present (2016), Russia is setting up bases in Syria, e.g. near Palmyra.

${ }^{16}$ For more on this, see the relevant chapters in Demski \& Laineste \& BaranieckaOlszewska 2015.

${ }^{17}$ Unlike the protests in Poznań in 1956, where the Soviet Army was on the alert.

${ }^{18}$ For more on memory politics viewed by a historian, an ethnologist, and a sociologist, see Dudek 2000, Korzeniewski 2010, and Szpociński 2015, respectively.

19 This statement draws on interviews with inhabitants of Borne Sulinowo, especially with those who were and are engaged in creating a place for tourists (e.g. organisers of the yearly Summer Military Vehicle Meeting), as well as on conversations with tourists visiting the town.

20 This interpretation of former military bases in the light of current Russia-Poland/ Europe relationships has been common since 2016.

${ }^{21}$ At the beginning of 2017, American armed forces were being stationed at the postSoviet base in Żagań (western Poland), and at other military sites.

${ }^{22}$ My discussion does not include situations in which bases are used for military purposes. This is a subject for a separate study. 


\section{REFERENCES}

Affelt, Waldemar 2009. Dziedzictwo techniki, jego różnorodność i wartości. [The Heritage of Technology, Its Diversity, and Value.] Kurier Konserwatorski, Vol. 5, pp. 5-20. Available at http://www.nid.pl/upload/iblock/858/85811d0a0b216dd273cefb36ee a5d6e1.pdf, last accessed on November 23, 2017.

Agnew, John A. 1987. Place and Politics: The Geographical Mediation of State and Society. London: Allen \& Unwin.

Albert, Marie-Theres 2007. Kultura, dziedzictwo, tożsamość. [Culture, Heritage and Identity.] In: Monika A. Murzyn \& Jacek Purchla (eds.) Dziedzictwo kulturowe w XXI wieku: Szanse i wyzwania. Kraków: Międzynarodowe Centrum Kultury, pp. 49-56.

Anderson, Benedict R. 1991 [1983]. Imagined Communities: Reflections on the Origin and Spread of Nationalism. New York: Verso.

Ashworth, Gregory J. \& Haan, Theo Z. de 1986. Uses and Users of the Tourist-Historic City. Veldstudies, Vol. 10. Groningen: Geografisch Instituut Rijksuniversiteit Groningen.

Ashworth, Gregory J. \& Graham, Brian \& Tunbridge, John E. 2007. Pluralising Pasts: Heritage, Identity and Place in Multicultural Societies. Chicago: The University of Chicago Press.

Bloch, Marc 2008. Dziwna klęska. [Strange Disaster.] Warszawa: Oficyna Naukowa.

Bokszański, Zbigniew 2008. Tożsamości zbiorowe. [Collective Identities.] Warszawa: Wydawnictwo Naukowe PWN.

Carman, John 2002. Archaeology and Heritage: An Introduction. Leicester: Continuum.

Chaney, David 2008 [2002]. The Power of Metaphors in Tourism Theory. In: Simon Coleman \& Mike Crang (eds.) Tourism: Between Place and Performance. New York \& Oxford: Berghahn Books, pp. 192-206.

Coleman, Simon \& Crang, Mike (eds.) 2008 [2002]. Tourism: Between Place and Performance. New York \& Oxford: Berghahn Books.

Crouch, David 2008 [2002]. Surrounded by Place: Embodied Encounters. In: Simon Coleman \& Mike Crang (eds.) Tourism: Between Place and Performance. New York \& Oxford: Berghahn Books, pp. 207-218.

Czarnecka, Dominika 2015a. "Pomniki wdzięczności” Armii Czerwonej w Polsce Ludowej i III Rzeczypospolitej. [Monuments of Gratitude to the Red Army in People's Poland and the Third Republic of Poland.] Warszawa: Wydawnictwo Instytutu Pamięci Narodowej.

Czarnecka, Dominika 2015b. Making Sense of the Past: (Re)constructing the Local Memorial Landscape in a Post-Soviet Base in Poland. Journal of Ethnology and Folkloristics, Vol. 9, No. 2, pp. 21-40. Available at http://www.jef.ee/index.php/ journal/article/view/204, last accessed on November 23, 2017.

Demski, Dagnosław \& Czarnecka, Dominika 2015. Mapping Meanings in the Post-Soviet Landscape of Borne Sulinowo. Latvijas Vēstures Institūta Žurnāls, No. 2 (95), pp. 96-120. Available at http://www.lvi.lv/lv/LVIZ_2015_files/2numurs/D_ Demski_D_Czarnecka_Mapping_LVIZ_2015_2.pdf, last accessed on November 23, 2017. 
Demski, Dagnosław \& Laineste, Liisi \& Baraniecka-Olszewska Kamila (eds.) 2015. War Matters: Constructing Images of the Other (1930s to 1950s). Budapest: L'Harmattan.

Dudek, Antoni 2000. Ślady PeeReLu: Ludzie, wydarzenia, mechanizmy. [Traces of the People of the Republic of Poland: People, Events, Mechanisms.] Kraków: ARCANA.

Falser, Michael 2015. Cultural Heritage as Civilizing Mission: From Decay to Recovery. Heidelberg \& New York: Springer.

Frejlich, Czesława (ed.) 2001. Rzeczy pospolite: Polskie wyroby 1899-1999. [Common Wealth: Polish Products 1899-1999.] Olszanica: Bosz.

Hirsch, Eric \& O'Hanlon, Michael (eds.) 1995. The Anthropology of Landscape: Perspectives on Place and Space. Oxford: Clarendon Press.

Hoffman, Barbara T. (ed.) 2006. Art and Cultural Heritage: Law, Policy, and Practice. Cambridge \& New York \& Melbourne \& Madrid \& Cape Town \& Singapore \& São Paulo: Cambridge University Press.

Holtorf, Cornelius J. 2001. Is the Past a Non-Renewable Resource? In: Robert Layton \& Peter G. Stone \& Julian Thomas (eds.) Destruction and Conservation of Cultural Property. London: Routledge, pp. 286-294.

Kiełczewska, Anna (ed.) 2011. Chcemy być nowocześni: Polski design 1955-1968 z kolekcji Muzeum Narodowego w Warszawie. [We Want to Be Modern: Polish Design 19551968 from the Collection of the National Museum in Warsaw.] Warsaw: Muzeum Narodowe w Warszawie.

Kobyliński, Zbigniew 2009. Własność dziedzictwa kulturowego: Idee - Problemy Kontrowersje. [Ownership of Cultural Heritage: Ideas - Problems - Conflicts.] Warszawa: IAE PAN.

Korzeniewski, Bartosz 2010. Transformacja pamięci: Przewartościowania $w$ pamięci przeszłości a wybrane aspekty funkcjonowania dyskursu publicznego o przeszłości $w$ Polsce po 1989 roku. [Transformation of Memory: Revaluations in the Memory of the Past and Selected Aspects of the Functioning of the Public Discourse about the Past in Poland after 1989.] Poznań: Wydawnictwo Poznańskiego Towarzystwa Przyjaciół Nauk.

Korzeniewski, Bartosz 2015. Przemiany obrazu drugiej wojny światowej w polskich muzeach po roku 1989. [The Transformation of the Image of World War II in Polish Museums after 1989.] In: Jerzy Kałążny \& Amelia Korzeniewska \& Bartosz Korzeniewski (eds.) Druga wojna światowa w pamięci kulturowej $w$ Polsce i w Niemczech: 70 lat później (1945-2015). [World War II in Cultural Memory in Poland and Germany: Seventy Years Later (1945-2015).] Gdańsk: Muzeum II Wojny Światowej, pp. 105-138.

Lowenthal, David 1985. The Past is a Foreign Country. New York: Cambridge University Press.

Lowenthal, David 1998 [1996]. The Heritage Crusade and the Spoils of History. Cambridge: Cambridge University Press.

Małachowicz, Edmund 2007. Konserwacja i rewaloryzacja architektury w środowisku kulturowym. [Preservation and Regeneration of Architecture in a Cultural Environment.] Wrocław: Oficyna Wydawnicza Politechniki Wrocławskiej. 
Massey, Doreen 1994. Space, Place and Gender. St. Paul: Minnesota University Press. Matthews, Christopher N. 2006. The Idea of the Site: History, Heritage, and Locality in Community Archaeology. In: Ludomir R. Lozny (ed.) Landscapes Under Pressure: Theory and Practice of Cultural Heritage Research and Preservation. New York: Springer, pp. 75-91.

Mendel, Maria 2010. Tożsamość zbiorowa jako lokalność. [Collective Identity as a Locality.] In: Maria Mendel \& Alicja Zbierzchowska (eds.) Tożsamość gdańszczan: Budowanie na (nie)pamięci. [Identity of the Inhabitants of Gdańsk: Building on (Non)Memory.] Gdańsk: Wydawnictwo Uniwersytetu Gdańskiego, pp. 371-395.

Rabinow, Paul (ed.) 1984. The Foucault Reader. New York: Pantheon Books. Available at https://monoskop.org/images/f/f6/Rabinow_Paul_ed_The_Foucault_Reader_1984. pdf, last accessed on November 24, 2017.

Relph, Edward 1976. Place and Placeless. London: Pion.

Sandis, Constantine (ed.) 2014. Cultural Heritage Ethics: Between Theory and Practice. Cambridge: Open Book Publishers.

Sørensen, Marie, L. S. \& Viejo-Rose, Dacia 2015. War and Cultural Heritage: Biographies of Place. Cambridge: Cambridge University Press.

Szpociński, Andrzej 2015. Polityka historyczna PRL-u w latach 1945-1985: Studium przypadku. [Historical Policy of the Polish People's Republic in the Years 19451985: Case Study.] In: Izabela Skórzyńska \& Dorota Skotarczak \& Stanisław Jankowiak (eds.) Społeczeństwo PRL 2: Kultura. Pamięć. Poznań: Instytut Historii UAM, pp. 203-214. 